https://doi.org/10.25208/0042-4609-2019-95-2-29-41

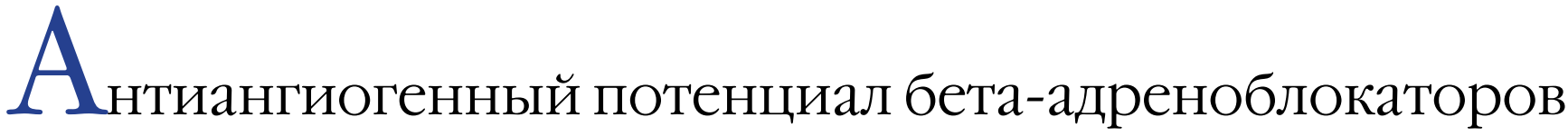 в аспекте лечения ювенильных гемангиом
}

Дубенский Вл. В.", Дубенский В. В.

Тверской государственный медицинский университет Министерства здравоохранения Российской Федерации 170100, Российская Федерация, г. Тверь, ул. Советская, д. 4

Ювенильные гемангиомы (ЮГ) - наиболее распространенные опухоли детского возраста, которые, по оценкам различных исследователей, встречаются у 3-12 \% новорожденных; возникающие при локальном развитии значительных нарушений регуляции неоангиогенеза.

Цель исследования: определение сравнительной антиангиогенной эфффективности и влияния бета-адреноблокаторов на уровень сосудистого эндотелиального фактора роста в эксперименте. Материалы и методы. Для определения антиангиогенного эффекта бета-адреноблокаторов выполнено сравнительное изучение их влияния на уровень сосудистого эндотелиального фактора роста в эксперименте на 72 нелинейных лабораторных крысах средней массой $180 \pm 20$ г, которые были условно разделены на 6 групп: 1 - контрольная, 2 - отрицательный контроль - экспериментальная ишемия (ЭИ, пересечение бедренных сосудов), 3 - положительный контроль (ЭИ с введением бевацизумаба), 4 - ЭИ с введением тимолола, 5 - ЭИ с введением бетаксолола, 6 - ЭИ с введением интерферона альфа-2b.

Результаты. Уровни VEGF составили: в 1-й группе 1,50 \pm 0,3 пг/мл, во 2-й $-20,3 \pm 3,2$ пг/мл, в 3-й $-5,8 \pm 0,9$ пг/мл, в 4-й - 13,8 $\pm 1,4$ пг/мл, в 5-й - 19,2 $\pm 2,3$ пг/мл и в 6-й - 11,1 $\pm 2,2$ пг/мл. Результаты микроскопии и ИГХИ свидетельствуют об отсутствии активации процессов неоангиогенеза в 1 группе животных. У животных 2 и 5 групп наряду с выраженными воспалительными процессами установлены явления неоангиогенеза.

Заключение. Бета-адреноблокаторы проявляют прямое или опосредованное негативное влияние на синтез VEGF и угнетение неоангиогенеза. Активность селективного бета-адреноблокатора в отношении подавления неоангиогенеза была ниже по сравнению активностью неселективного, что позволяет считать тимолол эфрфективным антиангиогенным средством.

Ключевые слова: эксперимент, ювенильные гемангиомы, гемангиомы новорожденных, бета-адреноблокаторы, тимолол, лөчение

Конфрликт интересов: исследования выполнены при поддержке Российского фонда фундаментальных исследований (РФФИ, грант 12-04-32096/12).

Для цитирования: Дубенский Вл. В., Дубенский В. В. Антиангиогенный потенциал бета-адреноблокаторов, в аспекте лечения ювенильных гемангиом. Вестник дерматологии и венерологии. 2019;95(2):29-41.

https://doi.org/10.25208/0042-4609-2019-95-2-29-41 


\title{
Antiangiogenic potential of beta-blockers in the context of juvenile hemangioma treatment
}

\author{
Vladislav V. Dubensky*, Valery V. Dubensky
}

Tver State Medical University, Ministry of Health of the Russian Federation Sovetskaya str., 4, Tver, 170100, Russian Federation

\begin{abstract}
Juvenile hemangiomas $(\mathrm{JH})$ - the most common tumor of childhood, which is estimated by various investigators found in 3-10\% of newborns resulting from the local development of significant violations of neoangiogenesis regulation.

Research objective: determination of comparative antiangiogenic effectiveness and influence of beta-blockers on the level of a vascular endothelial factor of growth in an experiment.

Material and methods. For determination of antiangiogenic effect of beta blockers, comparative studying of their influence on the level of a vascular endothelial factor of growth in an experiment on 72 nonlinear laboratory rats, by average weight $180 \pm 20 \mathrm{~g}$ which were conditionally divided into 6 groups is executed: 1 - control, 2 - negative control - experimental ischemia (EI, crossing of femoral vessels), 3 - positive control (El with bevacizumab introduction), $4-$ El with introduction of a timolol, 5 - El with introduction of a betaksolol, 6 - El with introduction of interferon alpha $2 \mathrm{~b}$.

Results. The VEGF levels were: in 1 group $-1.50 \pm 0.3 \mathrm{pg} / \mathrm{ml}$, in $2-20.3 \pm 3.2 \mathrm{pg} / \mathrm{ml}, 3-5.8 \pm 0.9 \mathrm{pg} / \mathrm{ml}$, $4-13.8 \pm 1.4 \mathrm{pg} / \mathrm{ml}, 5-19.2 \pm 2.3 \mathrm{pg} / \mathrm{ml}$ and $6-11.1 \pm 2.2 \mathrm{pg} / \mathrm{ml}$. Results of microscopy and immunohistochemical research demonstrate lack of activation of processes of neoangiogenesis in 1 group of animals. At animals of 2 nd and 5 th groups along with the expressed inflammatory processes the neoangiogenesis phenomena are established.

Conclusion. Beta-blockers show the direct or mediated negative impact on synthesis of VEGF and oppression of neoangiogenesis. The activity of selective beta-blocker concerning neoangiogenesis suppression - was lower in comparison by activity non-selective that allows to consider the Timolol effective antiangiogenic remedy.
\end{abstract}

Keywords: experiment, juvenile hemangioma, hemangioma of newborns, beta-blockers, timolol, treatment

Conflict of interest: the research was supported by the Russian Foundation for Basic Research (RFBR, grant No. 12-04-32096/12).

For citation: Dubensky VI. V., Dubensky V. V. Antiangiogenic potential of beta-blockers in the context of juvenile hemangioma treatment. Vestnik Dermatologii i Venerologii. 2019;95(2):29-41. https://doi.org/10.25208/0042-46092019-95-2-29-41 
Ювенильная гемангиома (ЮГ; гемангиома новорожденных) - распространенная врожденная сосудистая доброкачественная опухоль, выявляемая у 2-10 \% новорожденных [1-3].

В настоящее время существуют три гипотезы, которые объясняют этиологию ЮГ. Роль локальной гипоксии кожи была предложена в качестве сигнального механизма для развития ЮГ, поскольку она является мощным индуктором ангиогенеза. Формирование ЮГ рассматривается как компенсаторный механизм гомеостаза, направленный на восстановление оксигенации ткани в очаге гипоксии [4]. Другим предложенным механизмом является эмболизация плацентарных эндотелиальных клеток, которые вытесняются в фретальную циркуляцию во время беременности, фриксируясь к восприимчивым тканям, таким как кожа и печень [5-7]. Плацентарная гипотеза может объяснить, почему рост ЮГ происходит после рождения, из-за отсутствия ингибиторов ангиогенеза, которые вырабатываются плацентой [7]. Окончательная гипотеза об этиологии ЮГ относится к дисрегуляции ангиогенеза. Внутренние дефекты экспрессии рецептора 1 фрактора роста эндотелия сосудов (VEGFR-1) в эндотелиальных клетках гемангиомы и/или внутренняя активация сигнальных путей VEGF характеризуют фазу пролиферации ЮГ [8]. Эндотелиальные клетки также играют важную роль во время фразы инволюции, во время которой происходит изменение ангиоархитектоники ЮГ и апоптоз эндотелиальных клеток [9].

В сообщении группы исследователей (2008 г.) детского госпиталя Бордо (Франция) во главе с C. Leaute-Labreze отмечен регресс сложной ювенильной гемангиомы при системном лечении неселективным бета-адреноблокатором (пропранололом) [10]. Лечение проводили ребенку с пролиферирующей гемангиомой и кардиомиопатией, обусловленной предшествующей системной кортикостероидной терапией [10]. В последние годы появилось еще несколько сообщений, подтверждающих клиническую эффективность препарата [11].

Механизм действия пропранолола при лечении ЮГ до конца еще не изучен, но есть гипотеза о том, что ранние и отдаленные эффректы воздействия пропранолола на гемангиомы могут быть связаны с различными фрармакологическими механизмами. Ранние эфффекты (просветление поверхности гемангиомы в течение 1-3 дней от начала терапии) связаны с вазоконстрикцией (снижение высвобождения NO). Отдаленные эфффекты обусловлены блокированием проангиогенных сигналов, в результате чего подавляется рост сосудов и индуцируется апоптоз в пролиферирующих эндотелиальных клетках, что приводит к регрессу опухоли $[12,13]$.

Сосудистый эндотелиальный фактор роста (vascular endothelial growth factor, VEGF) - многофункциональный белок, отвечающий за восстановление нарушенного кровоснабжения тканей при повреждении. Кроме того, имеются указания на то, что VEGF выполняет важную фуннцию поддержания гомеостаза эндотелиального барьера, включающую регуляцию сосудистой проницаемости для воды и макромолекул, сосудистого тонуса, трансэндотелиальной миграции клеток, обладает васкулопротективными свойствами. В норме VEGF содержится в тканях в незначительном количестве, но экспрессия его гена значительно активируется при гипоксии через индукцию транскрипционного фак- тора HIF-1 (фактора, индуцируемого гипоксией). Многие тканевые клетки синтезируют VEGF — фрибробласты, эпителиальные, тучные и сами эндотелиальные клетки [14].

Ген VEGF состоит из восьми экзонов, разделенных между собой семью интронами. Свои эфффекторные функции VEGF осуществляет через два основных тирозинкиназных рецептора на клетках эндотелия VEGFR1 (Fltl) и VEGFR2 (Flkl/KDR), которые хорошо охарактеризованы. При связывании лиганда с рецептором происходит его димеризация с последующей активацией каталитической активности [14].

Бета-адреноблокаторы являются конкурентными ингибиторами связывания медиаторов симпатической нервной системы с бета-адренорецепторами. Впервые в клиническую практику бета-адреноблокаторы были внедрены 40 лет назад в качестве антиаритмических средств и при лечении стенокардии. В настоящее время они являются наиболее эффективными средствами вторичной профилактики после перенесенного острого инфаркта миокарда. В 1988 г. создателям бета-адреноблокаторов была присуждена Нобелевская премия.

Все бета-адреноблокаторы делятся на неселективные и селективные. Селективность - способность блокировать только бета1-адренорецепторы и не влиять на бета2-рецепторы, поскольку полезное действие бета-адреноблокаторов обусловлено преимущественно блокадой бета1-рецепторов, а основные побочные эффекты - бета2-рецепторов. Однако эта кардиоселективность лишь относительная - в больших дозах даже селективные бета-адреноблокаторы могут частично блокировать и бета2-адренорецепторы [15]. Дополнительно у некоторых бета-адреноблокаторов имеется так называемая внутренняя симпатомиметическая активность (BCA) - способность бета-адреноблокатора частично стимулировать подавляемые им бета-адренорецепторы, что снижает побочные эффректы («смягчает» действие) препарата [15]. Сила связывания со специфическим рецептором, или прочность связи лекарственного средства с рецептором, определяет концентрацию медиатора норадреналина, которая требуется для преодоления конкурентной связи на уровне рецептора. Как следствие, терапевтические дозы бисопролола и карведилола ниже, чем у атенолола, метопролола и пропранолола, у которых связь с бета-адренорецептором менее прочная [15].

Цель исследования - определение сравнительной эфффективности влияния бета-адреноблокаторов на уровень сосудистого эндотелиального фрактора роста в эксперименте.

\section{Материалы и методы}

Для определения антиангиогенного эффректа бета-адреноблокаторов выполнено экспериментальное сравнительное изучение влияния бета-адреноблокаторов, а также лекарственных препаратов с известным отрицательным влиянием на уровень сосудистого эндотелиального фактора роста (VEGF). 72 нелинейные лабораторные крысы средней массой $180 \pm 20$ г были условно разделены на 6 групп (табл. 1). Крысы 1-й группы являлись интактными (контрольная группа).

Учитывая, что во взрослом организме при отсутствии провоцирующих факторов уровень VEGF находится на базальном уровне с крайне низкими значе- 
Таблица 1. Характеристика групп экспериментальных животных

Table 1. Characterization of animals in the experimental groups

\begin{tabular}{|c|c|c|}
\hline Группа животных & Экспериментальная хроническая ишемия & Исследуемые фармакологические препараты \\
\hline $\begin{array}{c}1 \text { группа — контрольная (интактные } \\
\text { животные, } n=12 \text { ) }\end{array}$ & - & - \\
\hline 2 группа (отрицательный контроль, $\mathrm{n}=12$ ) & + & - \\
\hline $\begin{array}{c}3 \text { группа (сравнения 1, положительный } \\
\text { контроль, } \mathrm{n}=12 \text { ) }\end{array}$ & + & Бевацизумаб (антитела против VEGF) \\
\hline 4 группа (наблюдения $1, \mathrm{n}=12$ ) & + & Тимолол \\
\hline 5 группа (наблюдения 2, n = 12) & + & Бетаксолол \\
\hline 6 группа (сравнения $2, n=12$ ) & + & Интерферон альсра-2b \\
\hline
\end{tabular}

ниями, которые не позволят в полной мере оценить развитие антиангиогенного эфффекта, для его стимуляции выполнено моделирование хронической экспериментальной ишемии (ЭИ) одной конечности у крыс 2-й группы без введения фармакологических средств (отрицательный контроль). Крысам 3-й группы после операции ЭИ выполняли введение бевацизумаба. Введение бевацизумаба использовано в качестве «положительного контроля» - при введении данного препарата ожидается наибольшее угнетение синтеза VEGF. Бевацизумаб - рекомбинантные гиперхимерные (гуманизированные) моноклональные IgG1 антитела, которые селективно связываются и ингибируют биологическую активность фрактора роста эндотелия сосудов (VEGF) in vitro $и$ in vivo. Для сравнительного анализа антиангиогенного потенциала использовали тимолол (неселективный бета-адреноблокатор), бетаксолол (селективный бета-адреноблокатор), бевацизумаб и интерферон альфра-2b. В 4-й группе животных выполняли ЭИ и вводили раствор тимолола, в 5-й группе животным с ЭИ - бетаксосолол и в 6-й группе крысам на фоне ЭИ - интерферон альфа-2b. Животные 3-й и 6-й групп необходимы для сравнительной оценки потенциала ингибирования VEGF, т. к. бевацизумаб обладает выраженной блокадой синтеза VEGF (положительный контроль), а интерферон альфа-2b оказывает умеренное ингибирующее действие на данный фрактор роста.

Животные содержались в виварии, в металлических клетках с выдвижным дном, по 7-8 особей в каждой, в одинаковом световом и температурном режимах. Условия содержания животных и рацион питания соответствовали «Правилам лабораторной практики в Российской Федерации» (Приказ МЗ РФ от 19.06.2003 № 267). Крыс в эксперименте лечили в полном соответствии с Резолюцией ARVO «По использованию животных в экспериментальных исследованиях», Принципами лечения экспериментальных животных (публикация № 89-23 NIH от 1985 г.), «Директиве Совета ЕС от 24 ноября 1986 г. о сближении законов, постановлений и административных положений государств ЕС по вопросам защиты животных, используемых для экспериментальных и других научных целей (86/609/EEC)» и ныне действующим стандартам GMP (Good medical practice) и GLP (Good Laboratory Practice). Эксперимент проводился в весенний период.

Влияние лекарственных средств на уровень VEGF крови крыс в каждой из групп проводили методом иммуноферментного анализа (ИФА) на 5-е и 10-е сутки после эксперимента. Активность лекарственных средств выражалась в индексе подавления VEGF (I $\mathrm{I}_{\mathrm{VEGFSUP}}=$ отношение среднего значения VEGF в контроле к усредненному уровню VEGF в группе при воздействии исследуемого вещества $\times 100$ - коэффрициент естественного снижения VEGF).

Оценка неоангиогенеза оценивалась при микроскопическом и иммуногистохимическом исследовании (ИГХИ) биоптатов сегментов бедренной мышцы, которые были получены сразу после эвтаназии животных при выводе из эксперимента на 10-е сутки после операции. Окраска препаратов выполнена гематоксилиномэозином и антителами против CD34 (CD34 - маркер прогениторных клеток, в том числе клеток-предшественниц эндотелия, позволяющий выявить капилляры на более ранней стадии развития [8], определение площади $\left(p x^{2}\right) \mathrm{CD}_{3} 4^{+}$выполнено в программе NIS Elements Basic Research.

\section{Техника моделирования хронической ишемии}

Условия хронической ишемии выполнены у животных 2, 3, 4, 5 и 6-й групп, 1-я группа - контрольная (интактные животные).

Перед операцией крысам выполнялась химическая депиляция шерсти (крем для депиляции «Veet») в области нижней части брюшной стенки и правой нижней конечности (рис. 1а).

Протокол операции: после обработки операционного поля раствором 70 \% этанола под местной инфрильтрационной анестезией $(2 \mathrm{ml} 2 \%$ раствора лидокаина) в проекции правой паховой связки выполнен косой разрез кожи длиной до 10-14 мм (рис. 1б). После разреза кожи и поверхностной фрасции «тупо» выделялись бедренная артерия и вена (рис. 1в). Выполнялась перевязка и пересечение сосудов между лигатурами (рис. 1г). Рана ушивалась отдельными узловыми швами синтетической рассасывающейся нитью.

Сравнительный анализ антиангиогенного потенциала бета-адреноблокаторов

Для определения влияния бета-адреноблокаторов на уровень сосудистого эндотелиального фрактора роста в эксперименте выполнено сравнительное изучение действия селективного и неселективного бета-адреноблокатора, а также лекарственных препаратов с известным отрицательным влиянием на VEGF (бевацизумаб, интерферон альфа). Введение бевацизумаба использовано в качестве «положительного контроля» - при введении данного препарата ожидается наибольшее угнетение синтеза VEGF. 

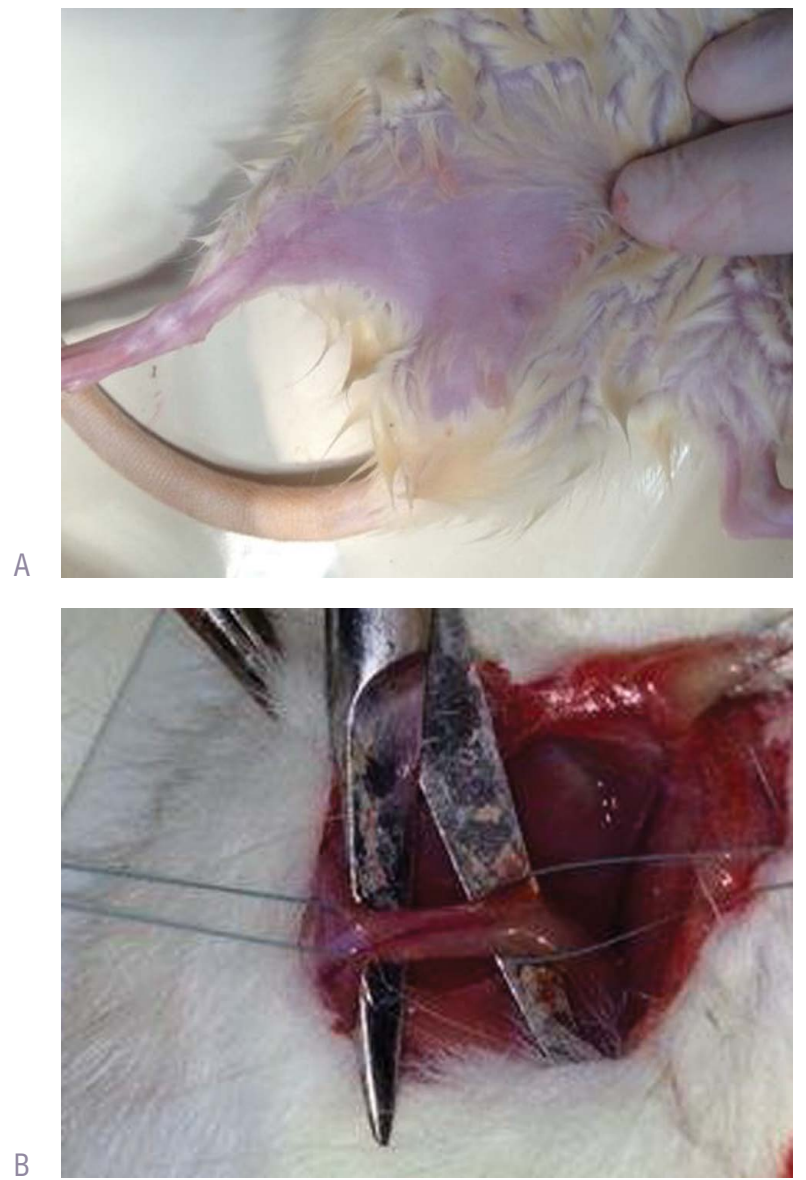
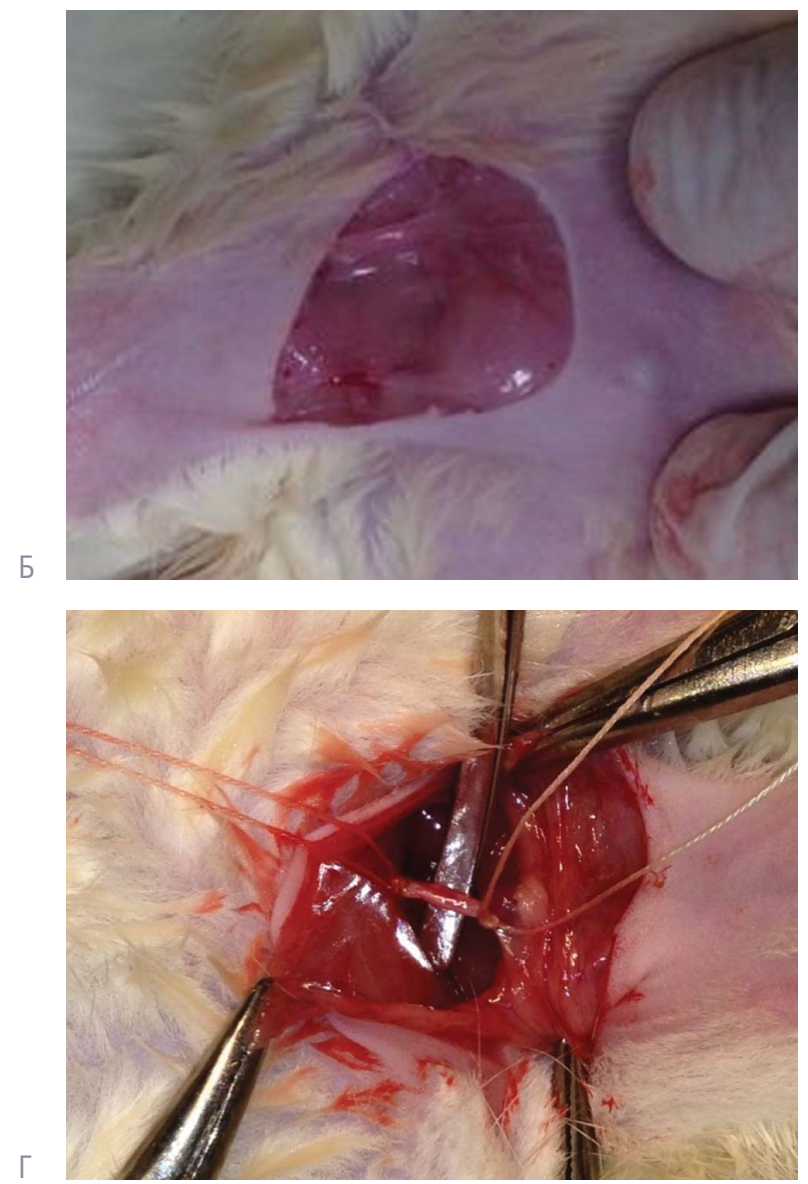

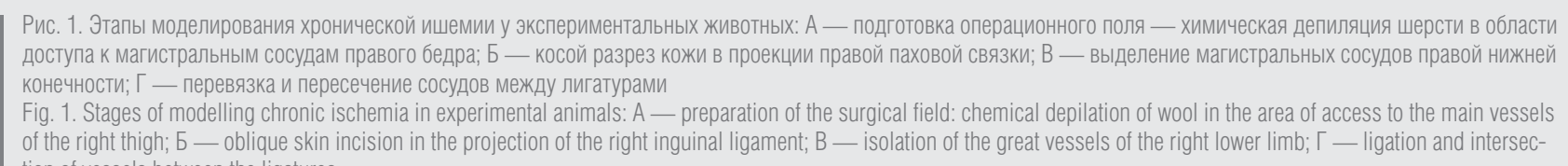
tion of vessels between the ligatures

Крысам 2-й группы для выявления уровня VEGF при условиях экспериментальной ишемии была выполнена только операция моделирования хронической ишемии без введения фрармакологических средств (отрицательный контроль). Крысы 1-й группы являлись интактными - им не выполнялась экспериментальная ишемия и не применялись лекарственные средства (контрольная группа).

Для сравнительного анализа антиангиогенного потенциала использовали: тимолол (неселективный бета-адреноблокатор), бетаксолол (селективный бета-адреноблокатор), бевацизумаб и интерферон альфpa-2b.

Крысам 3-й группы после операции выполняли введение бевацизумаба. В 4-й группе вводили раствор тимолола, в 5-й группе - бетаксолол и в 6-й группе интерферон альфа-2b.

Животные 3-й и 6-й групп необходимы для сравнительной оценки потенциала ингибирования VEGF, т. к. бевацизумаб обладает выраженной блокадой синтеза VEGF (положительный контроль), а интерферон альфа-2b оказывает умеренное ингибирующее действие на этот фактор роста.

Введение необходимой дозы лекарственных веществ осуществлялось в 1 мл стерильного 0,9\% раствора натрия хлорида внутрибрюшинно. Количество вводимых веществ рассчитывалось исходя из суточной дозы для человека в соответствии с «Методическими указаниями по проведению доклинических исследований фрармакокинетики фрармакологических веществ и лекарственных средств» [16] (табл. 2).

Необходимая концентрация достигалась путем разведения 1 мл раствора с известным содержанием лекарственного вещества фризиологическим раствором. Растворы тимолола и интерферона альфа-2b с учетом времени полувыведения (Т1/2) вводились дважды в сутки, бетаксалола - 1 раз, бевацизумаб - сразу после операции и на 5-е сутки.

Исследование уровня VEGF крови у крыс в каждой из групп проводили методом ИФА на 5-е и 10-е сутки у животных, выведенных из эксперимента. Кровь для исследования получали из хвостовой вены (0,5 мл). ИФА проводили по стандартной методике с набором реагентов Rat vascular endothelial cell growth factor, Cusabio Biotech Co., Ltd (Китай). Животные, которым выполнено взятие крови на 5-е сутки, выводились из эксперимента в связи с тем, что травма во время взятия крови могла стимулировать дополнительный выброс VEGF и исказить результаты анализа. 
Таблица 2. Расчет доз лекарственных средств, использованных в эксперименте

Table 2. Calculation of the doses of preparations used in the experiment

\begin{tabular}{|c|c|c|c|c|}
\hline Препарат & $T 1 / 2$ & $\begin{array}{c}\text { Доза для человека (70 кг), } \\
\text { мг/сутки }\end{array}$ & $\begin{array}{c}\text { Доза для крысы (200 г), } \\
\text { мг/сутки }\end{array}$ & Кратность введения \\
\hline Тимолол & 44. & 1 & 0,02 & 2 раза в сутки \\
\hline Бетаксолол & 14-22 ч. & 2 & 0,04 & 1 раз в сутки \\
\hline Бевацизумаб & $\begin{array}{l}\text { Начальное - } 1,4 \text { дня; } \\
\text { конечное } 20 \text { и } 19 \text { дней }\end{array}$ & 350 & 6,25 & 1 раз в 5 дней \\
\hline Интерфрерон альфра-2b & $2-64$. & 5,7 млн ME & 100 тыс. ME & 2 раза в сутки \\
\hline
\end{tabular}

Оценка степени выраженности неоангиогенеза в зоне экспериментальной ишемии проводилась при иммуногистохимическом исследовании (ИГХИ) биоптатов сегментов бедренной мышцы, которые были получены сразу после эвтаназии животных при выводе из эксперимента на 10-е сутки после операции. Окраска препаратов выполнена антителами против CD34 (маркер эндотелиоцитов кровеносных сосудов, CD34 Antibody Rabbit Polyclonal Applications E, WB, IHC, ABBIOTEC, SanDiego) и гематоксилином-эозином. Подготовка, проводка и окраска выполнены по общепринятым методикам.

При микроскопии препаратов обращали внимание на выраженность воспалительных реакций и некротических процессов, состояние капиллярной сети. При ИГХИ оценивали количество CD34+ клеток (окрашены в коричневый цвет, хромоген - диамино-бензидин). Определение площади $\left(\mathrm{px}^{2}\right) \mathrm{CD}^{2} 4^{+}$, окрашенной диамино-бензидином, выполнено в программе NIS Elements Basic Research.

Статистический анализ результатов ИГХИ и ИФА VEGF крови крыс выполнялся в программной среде IBM SPSS с применением дисперсионного анализа апостериорного критерия Дункана и бутстреп дисперсионного анализа апостериорного критерия Дункана соответственно. Параметры бутстрепа: количество выборок 1000, ДИ: 95 \%, тип доверительного интервала - процентиль; подмножество для $\alpha(p)=0,05$.

Результаты исследования и обсуждение

Уже на 1-е сутки после создания условий хронической ишемии у крыс всех экспериментальных групп

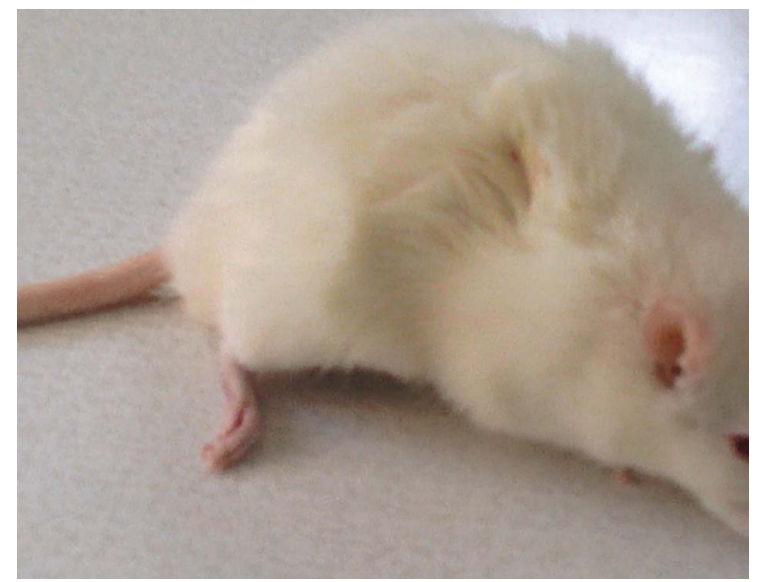

отмечено развитие полного пареза нижней конечности на оперированной стороне (рис. 2а), при этом на конечности определялся выраженный отек и цианоз (рис. 2б).

При макроскопической оценке состояния оперированных конечностей на 10-е сутки установлено хорошее заживление операционных ран во второй группе крыс (выполнена только экспериментальная ишемия) и пятой группе (экспериментальная ишемия и ежедневное введение бетаксолола), с явными процессами реваскуляризации конечности (за счет выраженного развития коллатералей, рис. За, б).

Развитие значительных деструктивных процессов мягких тканей правой нижней конечности установлено у животных третьей группы, которым выполнена экспериментальная ишемия и вводился бевацизумаб (рис. 4а). Умеренно выраженные воспалительные и деструктивные изменения (рис. 4б) выявлены в четвертой и шестой группах экспериментальных животных (экспериментальная ишемия в сочетании с ежедневным введением тимолола и интерферона соответственно).

При ИФА исследовании показателей VEGF в плазме экспериментальных животных на 5-е сутки после формирования экспериментальной ишемии средние показатели составили: в 1-й группе (контрольная - интактные животные) $-1,50 \pm$ 0,26 пг/мл, во 2-й группе (животные с хронической ишемией одной конечности) $-20,33 \pm$ 3,16 пг/мл, в 3-йгруппе (хроническая ишемия и введение бевацизумаба) - 5,80 $\pm 0,90$ пг/мл, в 4-йгруппе (хроническая ишемия и введение тимолола) $-13,87 \pm 1,40$ пг/мл, в 5-й группе (хроническая ишемия и введение бетаксолола) - 19,27 $\pm 2,31$ пг/мл и уровень VEGF у крыс

Рис. 2. Результат операции через 1 сутки: A — парез конечности на стороне выполненной операции; Б — выраженная отечность и цианоз обездвиженной правой конечности

Fig. 2. The result achieved 1 day after the operation: A — paresis of the limb on the side of the performed operation; $\overline{6}$ - severe swelling and cyanosis of the immobilized right limb 

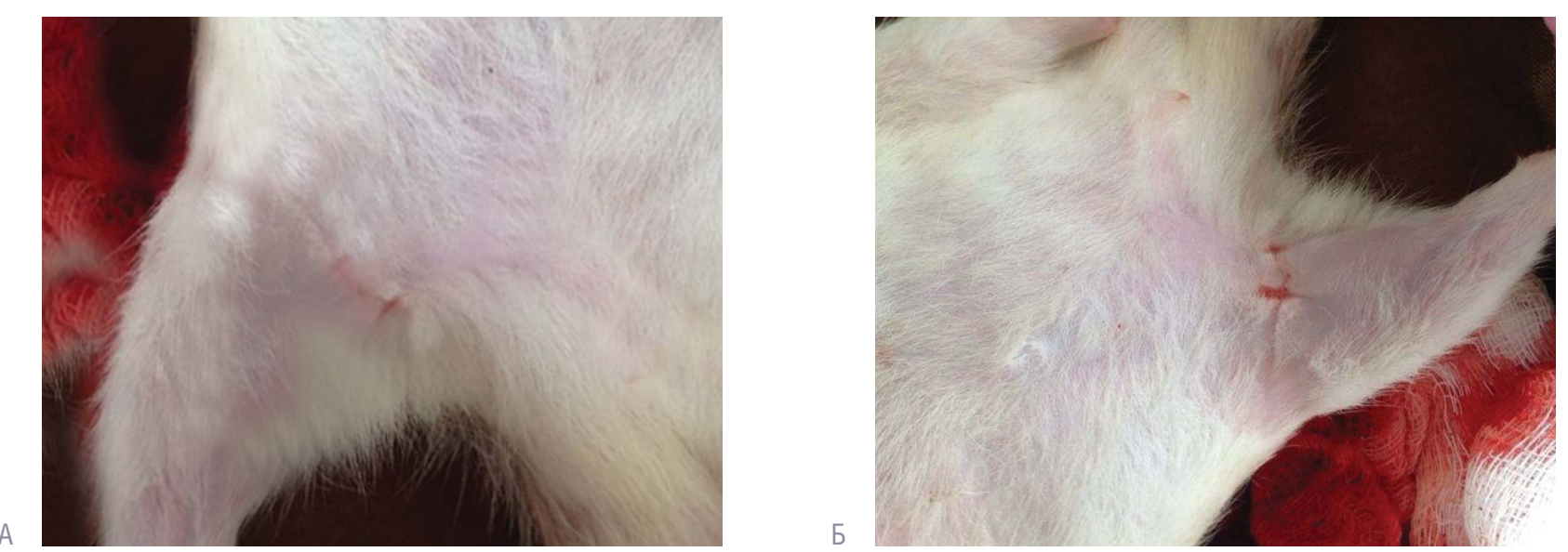

Рис. 3. Состояние послеоперационной области у экспериментальных животных 2-й и 5-й групп на 10 сутки: А - полное заживление послеоперационной раны и реваскуляризация конечности за счет компенсаторного развития коллатералей (2-я группа животных); Б - реваскуляризация конечности и полное заживление послеоперационной раны (5-я группа животных)

Fig. 3. Postoperative region in experimental groups 2 and 5 on the 10th day: A — complete healing of postoperative wounds and the revascularization of the limb due to the compensatory development of collaterals (experimental group 2); 5 — revascularization of the limb and complete healing of the postoperative wound (experimental group 5 )
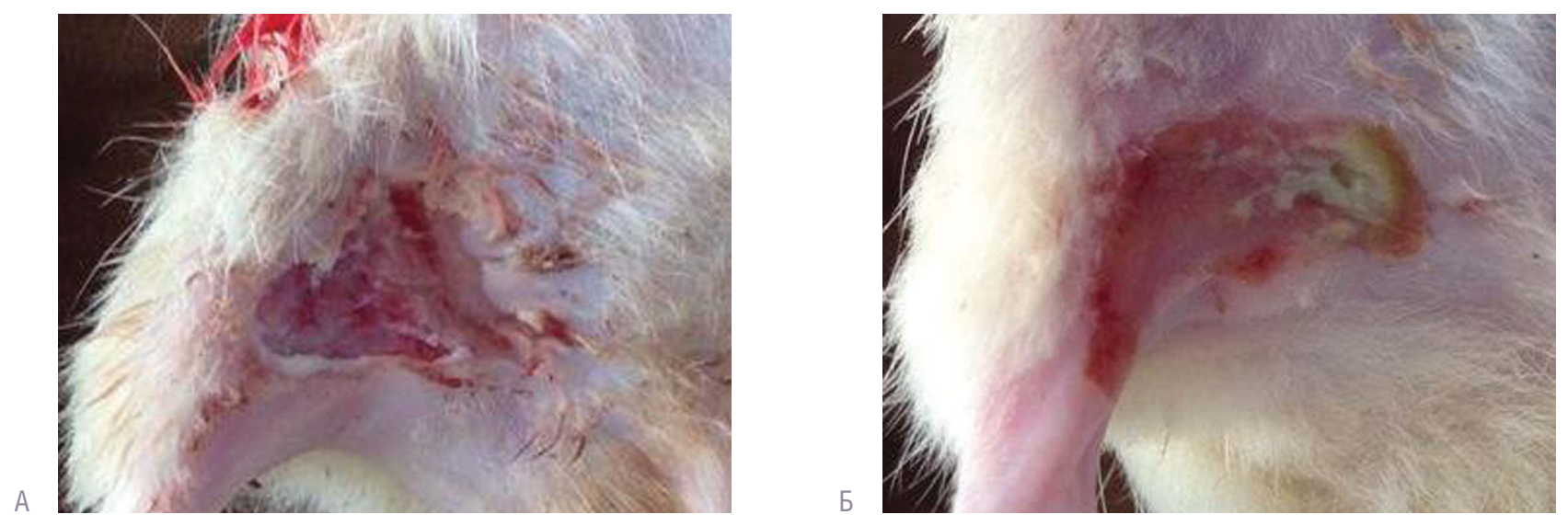

\footnotetext{
Рис. 4. Состояние послеоперационной области у экспериментальных животных 2-й и 5-й групп на 10 сутки: А — развитие глубоких деструктивных процессов мягких тканей в послеопреационной области и правой нижней конечности (3-я группа животных); Б - умеренно выраженные некротические процессы в области экспериментальной зоны и правой нижней конечности с признаками ишемизации у животных 4-й и 6-й групп

Fig. 4. Postoperative region in experimental groups 2 and 5 on the 10th day: A - development of deep destructive processes in soft tissues in the postoperative region and the right lower extremity (experimental group 3); 5 - moderately pronounced necrotic processes in the experimental zone and the right lower extremity with signs of ischemization in experimental groups 4 and 6
}

6-й группы (хроническая ишемия и введение интерферона альфа-2b) $-11,13 \pm 2,24$ пг/мл (рис. 5).

Таким образом, установлены достоверные отличия $(p=0,05)$ уровня VEGF на 5-е сутки в условиях экспериментальной ишемии между показателями в 1-й группе (контрольная), 3-й (группа сравнения 1 - положительный контроль), 4-й (группа наблюдения 1, которым вводился тимолол) и 6-й (группа сравнения 2, вводился интерферон). Результаты ИФА во 2-й и 5-й группах также имели достоверные отличия от показателей в других экспериментальных группах, но между собой отличия были не достоверны ( $p=0,05)$.

Полученные результаты ИФА VEGF в различных экспериментальных группах животных свидетельствуют о низких (базальных) показателях VEGF в контрольной группе (интактные крысы 1,50 \pm 0,26 пг/мл). Отмечены компенсаторно высокие показатели VEGF в группе крыс, которым выполнены экспериментальные условия хронической ишемии (2-я группа - отрицательный контроль, 20,33 \pm
3,16 пг/мл). В 3-й группе животных (положительный контроль), которым вводился бевацизумаб, установлено значительное снижение VEGF (5,80 \pm 0,90 пг/мл), уровень которого должен увеличиваться в условиях экспериментальной ишемии.

Интересным представляется анализ результатов ИФA VEGF в группах животных, которым вводились бета-адреноблокаторы, - 4-я группа (тимолол) и 5-я (бетаксолол). Несмотря на то что уровень VEGF у этих животных был выше $(13,87 \pm 1,4$ и 19,27 \pm 2,31 пг/мл соответственно) таковых в положительном контроле (3 группа, 5,80 \pm 0,90 пг/мл) и при введении крысам интерферона альфа-2b (6-я группа, 11,13 \pm 2,24 пг/мл), обращает на себя внимание достоверное снижение показателя VEGF у крыс при введении раствора тимолола по сравнению с результатами отрицательного контроля (2-я группа, 20,33 \pm 3,16 пг/мл, p = 0,05). Уровень VEGF при введении селективного бета-адреноблокатора бетаксолола (5 группа, 19,27 \pm 2,31 пг/мл) в данной стадии эксперимента не имеет достоверных отличий 


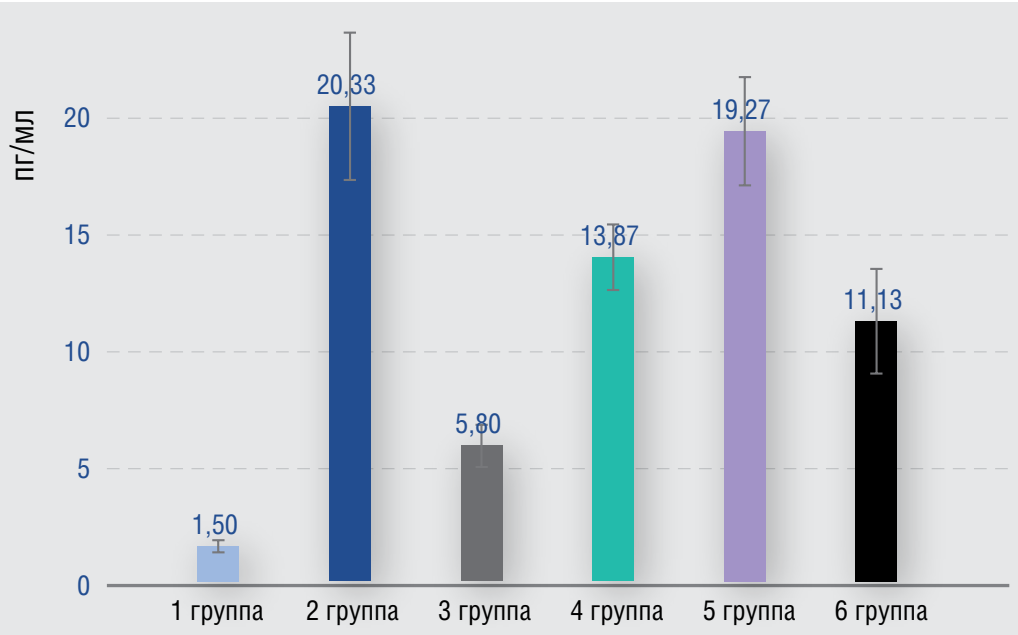

Рис. 5. Уровень VEGF сыворотки в группах животных на 5-е сутки в условиях экспериментальной ишемии и введении изучаемых средств (пг/мл) Fig. 5. VEGF serum levels in the experimental animals on the 5 th day under the conditions of experimental ischemia and administration of the preparations under study ( $\mathrm{pg} / \mathrm{ml}$ )

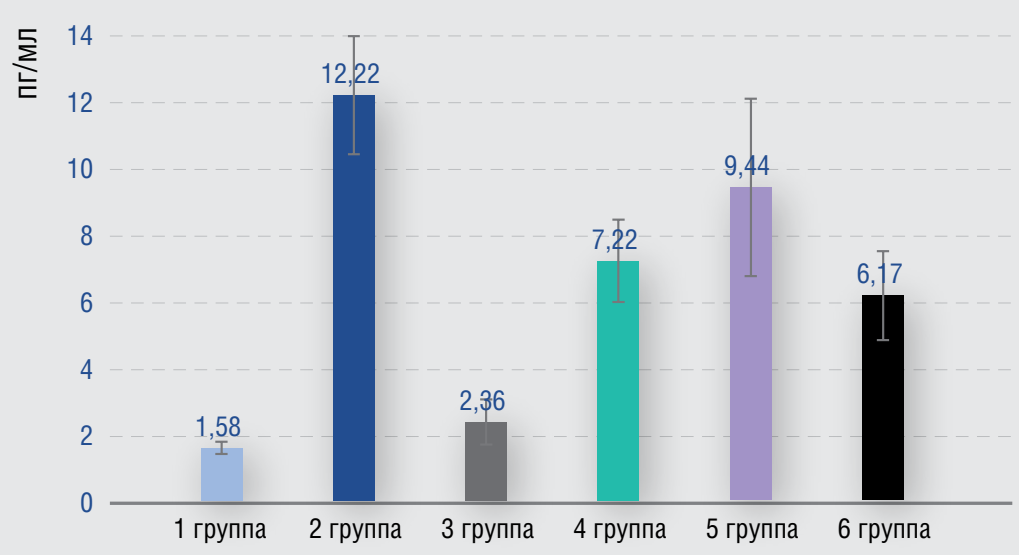

Рис. 6. Уровень VEGF сыворотки в группах животных на 10-е сутки в условиях экспериментальной ишемии и введении изучаемых средств (пг/мл)

Fig. 6. VEGF serum levels in the experimental groups on the 10th day under the conditions of experimental ischemia and administration of the preparations under study (pg/ml)

при сравнении с показателями отрицательного контроля (2-я группа, 20,33 \pm 3,16 пг/мл, $p=0,05)$.

На 10-е сутки в условиях экспериментальной ишемии исследован уровень VEGF сыворотки у оставшихся 36 крыс, при этом средние показатели VEGF плазмы крыс на 10-е сутки составили: в 1-й группе (контрольная - интактные животные) - 1,58 \pm 0,19 пг/мл, во 2-й группе (животные с хронической ишемией одной конечности) - 12,22 \pm 1,78 пг/мл, в 3-й группе (хроническая ишемия и введение бевацизумаба) $-2,36 \pm$ 0,68 пг/мл, в 4-й группе (хроническая ишемия и введение тимолола) - 7,22 \pm 1,24 пг/мл, в 5-й группе (хроническая ишемия и введение бетаксолола) - 9,44 \pm 2,67 пг/мл и уровень VEGF у крыс 6-й группы (хроническая ишемия и введение интерферона альфа-2b) 6,17 $\pm 1,34$ пг/мл (рис. 6).

При анализе результатов ИФА на 10-е сутки отмечается снижение уровня VEGF во всех группах животных (рис. 7), за исключением контрольной 1-й группы крыс (интактных), у которых установлено недостоверное увеличение показателя $(1,50 \pm 0,26$ и 1,58 \pm $0,19$ пг/мл соответственно, $p=0,05)$. Во 2-й группе животных, которым выполнена только экспериментальная ишемия, также отмечается снижение показателей
VEGF $(20,33 \pm 3,16$ и 12,22 \pm 1,78 пг/мл соответственно), что, вероятно, связано с восстановлением кровоснабжения за счет неоангиогенеза, реваскуляризации и развития коллатералей.

При статистическом анализе результатов исследования ИФА VEGF установлены однородные показатели в 1-й и 3-й группах крыс и 4-й и 6-й группах $(p=0,05)$. Таким образом, анализ указывает на высокое угнетение VEGF при введении бевацизумаба (3-я группа), сходном антиангиогенном потенциале тимолола и интерферона $(7,22 \pm 1,24$ и 6,17 $\pm 1,34$ пг/мл соответственно, $p=0,05)$ и меньшей активности селективного бета-адреноблокатора - бетаксолола $(9,44 \pm 2,67$ пг/мл, $\mathrm{p}=0,05)$. Вместе с тем, учитывая высокую скорость реваскуляризации конечности у крыс в условиях экспериментальной ишемии, приводящей к восстановлению гемодинамики и снижению VEGF, что продемонстрировано при анализе результатов ИФА на 5-е и 10-е сутки в отрицательном контроле (2-я группа животных), выполнено определение индекса подавления VEGF (I $\left.{ }_{\text {VEGFSUP }}\right)$ для изучаемых лекарственных средств.

Определение $\mathrm{I}_{\mathrm{VEGFSUP}}$ позволяет рассматривать антиангиогенный эффект исследуемых препаратов с учетом компенсаторного восстановления кровотока 


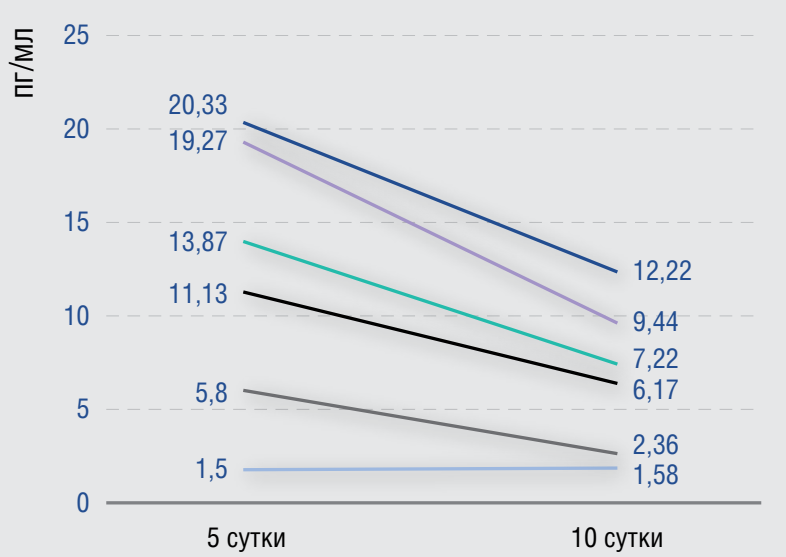

Рис. 7. Динамика VEGF сыворотки крыс в экспериментальных группах на 5-е и 10-е сутки эксперимента (пг/мл) Fig. 7. Dynamics of rat VEGF serum in the experimental groups on the 5 th and 10 th day of the experiment ( $\mathrm{pg} / \mathrm{ml})$
2 группа (хроническая ишемия, отрицательный контроль)

- 3 группа (ишемия+бевацизумаб, положительный контроль)

4 группа (ишемия+тимолол)

5 группа (ишемия+бетаксолол)

6 группа (ишемия+интерферон а2b)
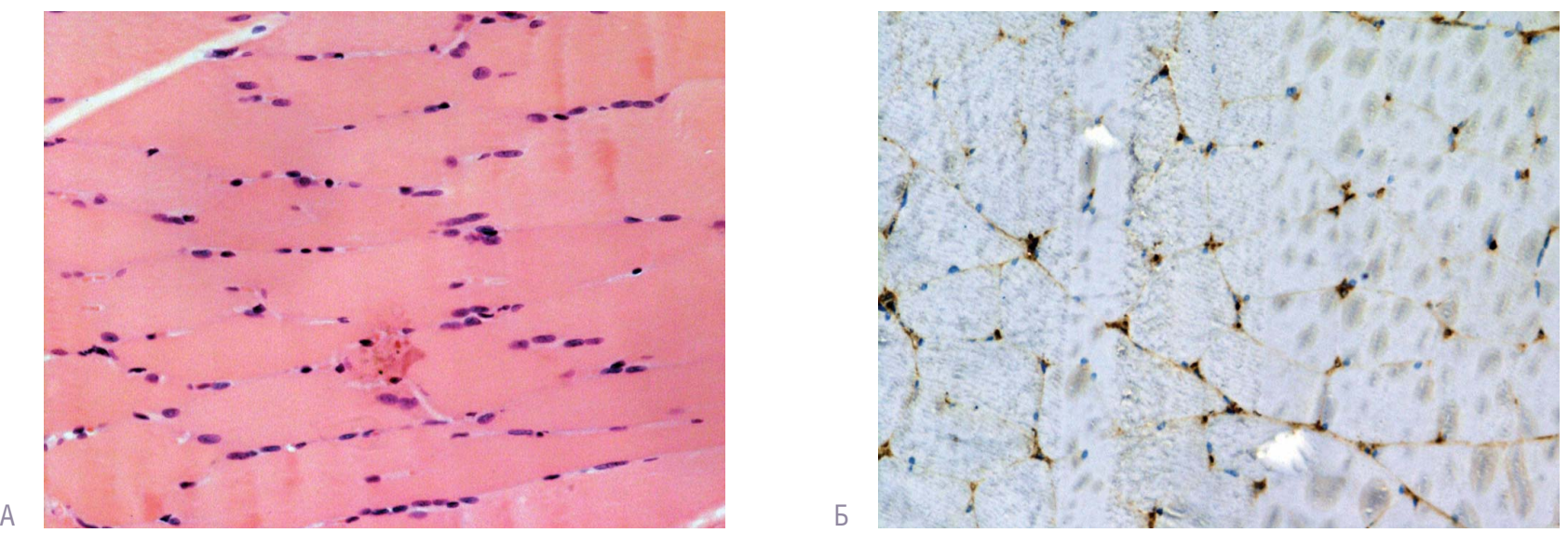

Рис. 8. Микроскопия мышечной ткани бедра экспериментальных животных 1-й группы на 10 сутки: А — Гематоксилин-эозин, х200. Капиллярная сеть в мышечной ткани у животных первой группы (интактные); Б — ИГХИ с антителами против CD34, х200. Капиллярная сеть вокруг мышечных волокон без признаков неоангиогенеза у крыс первой группы (интактные)

Fig. 8. Microscopy of the muscular tissue of the thigh in experimental group 1 on the 10th day: A - Hematoxylin-eosin, $\times 200$. Capillary network in the muscle tissue in experimental group 1 (intact); 5 _ Immunohistochemistry with antibodies against CD34, $\times 200$. The capillary network around the muscle fibres with no signs of neoangiogenesis in experimental group 1 (intact)

в экспериментальной зоне, приводящем к снижению уровня сосудистого эндотелиального фрактора роста.

Показатели $\mathrm{I}_{\mathrm{VEGFSUP}}$ свидетельствуют об ожидаемо высокой активности негативного влияния бевацизумаба на уровень VEGF $\left(I_{\text {VEGFSUP }}=28,28\right)$, умеренной при введении интерферона альфа-2b и раствора тимолола $(8,33$ и 5,14 соответственно). При этом установлено, что селективный бета-адреноблокатор бетаксолол оказывает наименьший эфрфект в отношении VEGF $\left(I_{\text {VEGFSUP }}=1,26\right)$.

Таким образом, бета-адреноблокаторы обладают антиангиогенным потенциалом, обусловленным отрицательным влиянием на VEGF, который оказался более выраженным у неселективного бета-адреноблокатора (тимолола) по сравнению с селективным - бетаксололом.

\section{Результаты гистологического исследования мышечной ткани и ИГХИ с антителами против CD34 у экспериментальных животных}

При изучении морфологических препаратов мышечной ткани в биоптатах бедренных мышц у животных первой группы (интактные) выявлена мышечная ткань нормального строения, без признаков воспалительного процесса (рис. 8а).

При ИГХ-исследовании с антителами кCD34 у экспериментальных животных первой группы выявлена интактная капиллярная сеть, расположенная вокруг мышечных волокон, без признаков неоангиогенеза (рис. 8б).

В гистологических препаратах мышечной ткани 2-й группы крыс (выполнена экспериментальная хроническая ишемия), выявлены выраженные деструктивные и воспалительные изменения, определяются массивные полиморфные инфильтраты с выраженным неоангиогенезом (рис. 9а).

При ИГХ-исследовании с антителами к CD34 биоптатов бедренных мышц у крыс второй группы выявляется выраженный неоангиогенез с формированием новых капилляров (рис. 9б). Данные процессы свидетельствуют о выраженной ишемии и компенсаторном развитии новых путей для питания поврежденной конечности.

Морфологическая картина биоптата бедренной мышцы крыс 3-й группы характеризовалась выраженными воспалительными инфильтратами, которые распростра- 

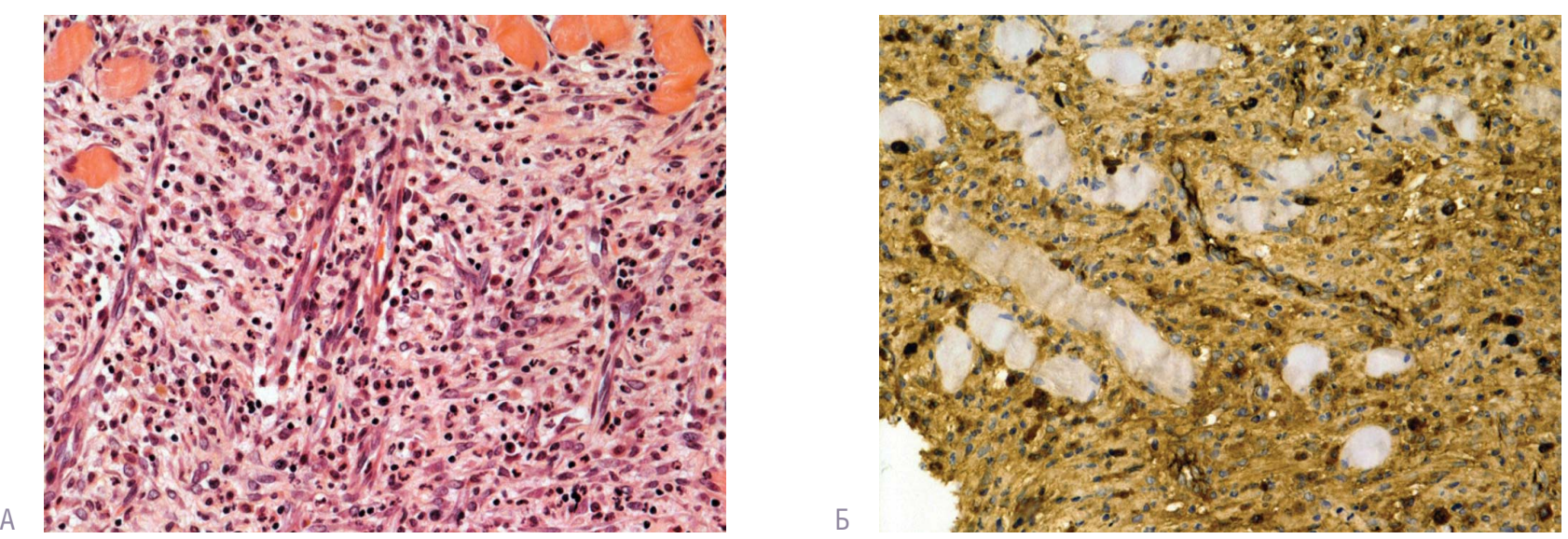

Рис. 9. Микроскопия мышечной ткани бедра у экспериментальных животных 2-й группы на 10-е сутки: А — Гематоксилин-эозин, х400. Мышечная ткань бедра с выраженным воспалительным полиморффным инфильтратом. Среди клеток воспалительного инсфильтрата имеются признаки ангиогенеза; Б - ИГХИ с антителами против СD34, ×200. Отек соединительной ткани, лимфогистиоцитарная инфильтрация. Пролиферация эндотелиоцитов вокруг мышечных волокон, формирование новых капилляров Fig. 9. Microscopy of the muscular tissue of the thigh in experimental group 2 on the 10th day: A - Hematoxylin-eosin, $\times 400$. Muscle tissue of the thigh with a pronounced inflammatory polymorphic infiltrate. The cells of the inflammatory infiltrate demonstrate signs of angiogenesis; 5 - Immunohistochemistry with antibodies against CD34, ×200.

Edema of the connective tissue, lymphohistiocytic infiltration. Proliferation of endotheliocytes around muscle fibres, formation of new capillaries
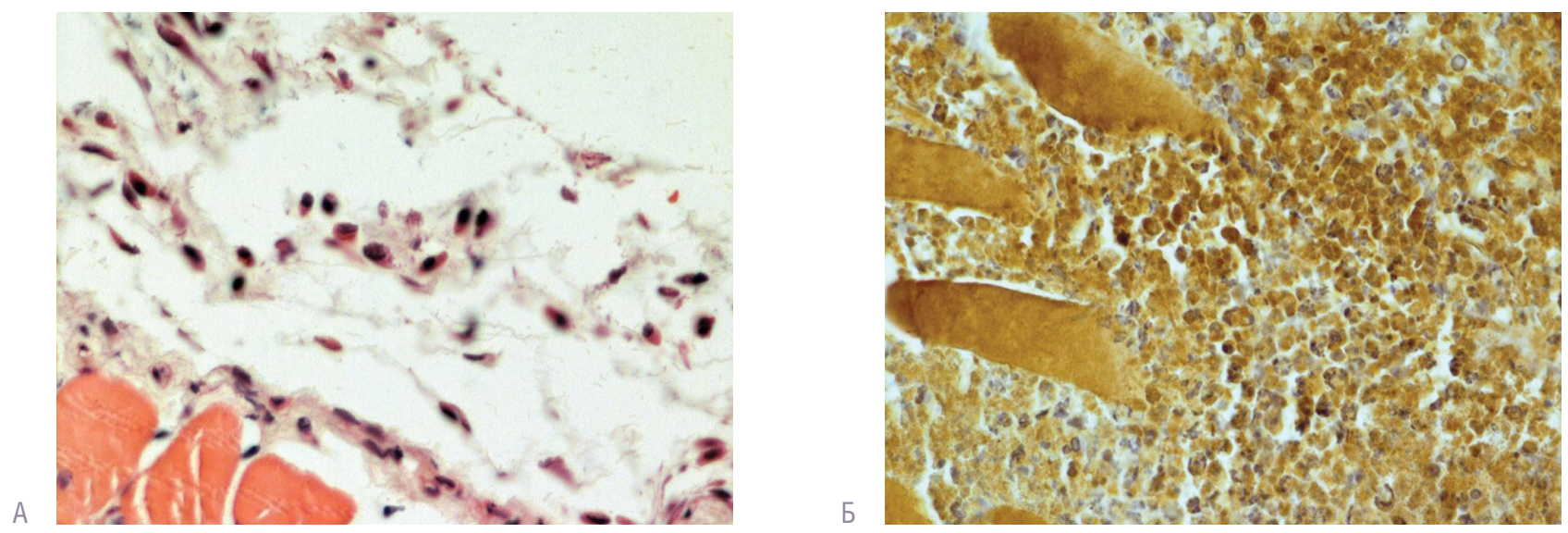

\footnotetext{
Рис. 10. Микроскопия мышечной ткани бедра экспериментальных животных 3-й группы (хроническая ишемия и введение бевацизума) на 10-е сутки: А - Гематоксилин-эозин, ×400. Отек соединительной ткани, выраженная лимфогистиоцитарная инфильтрация; Б — ИГХИ с антителами против СD34, ×400. Воспаление и отек мышечной и соединительной ткани. Отсутствие явлений неоангиогенеза

Fig. 10. Microscopy of the muscular tissue of the thigh in experimental group 3 (chronic ischemia and administration of bevacizumab) on the 10th day: A - Hematoxylin-eosin $\times 400$. Edema of the connective tissue, severe lymphohistiocytic infiltration; 5 - Immunohistochemistry with antibodies against CD34, $\times 400$. Inflammation and swelling of muscle and connective tissue. Absence of neoangiogenesis phenomena
}

нялись не только на мышечную ткань, но и подкожную жировую клетчатку (рис. 10).

Морфологическая картина мышечных биоптатов 4, 5 и 6-й групп экспериментальных животных характеризовалась умеренными воспалительными изменениями, признаками восстановления тканей и явлениями неоангиогенеза (рис. 11a). Незначительные отклонения имелись в степени выраженности пролиферации эндотелиоцитов. Так, в 4-й группе экспериментальных животных отмечены умеренные явления неоангиогенеза (рис. 11б), в 5-й - более интенсивные, с формированием полноценных микрососудов (рис. 12а) и в 6-й группе установлены начальные признаки пролиферации эндотелиоцитов (рис. 12б).

Проведено определение площади $\left(\mathrm{px}^{2}\right)$ и процента $\mathrm{CD} 34^{+}$, окрашенной диамино-бензидином, во всех экспериментальных группах животных (табл. 3).

Анализ результатов сравнения площади свидетельствует о достоверных отличиях $(p=0,05)$ между средни- ми значениями экспериментальных групп. Наибольшие показатели CD34+ площади установлены в препаратах 2-й группы (животные с хронической ишемией одной конечности, 142 102,02 \pm 32 486,06 рx²), наименьшая площадь выявлена в 1-й (контрольной) группе животных - $10880,00 \pm 5222,58$ рx². Среди изучаемых групп меньшая площадь CD34+ установлена в препаратах животных 3-й группы (хроническая ишемия и введение бевацизумаба - положительный контроль, 40 473,91 18 034,30 px²). При сравнении результатов в 4-й и 5-й группах: наименьшая площадь CD34+ определяется в образцах животных, которым выполнена хроническая ишемия и вводился тимолол, по сравнению с бетаксололом (91 555,33 \pm 13 083,43 и 127 967,23 28 878,79 рх ${ }^{2}$ соответственно). При введении интерферона альфа-2b (6-я группа, 82 838,02 \pm 19 460,15 рx²) площадь препарата $\mathrm{CD}_{34}{ }^{+}$оказалась меньше соответствующих показателей во 2-й (142 102,02 \pm 32 486,06 px²), 4-й (91 555,33 $\pm 13083,43$ px$\left.^{2}\right)$ и 5-й 

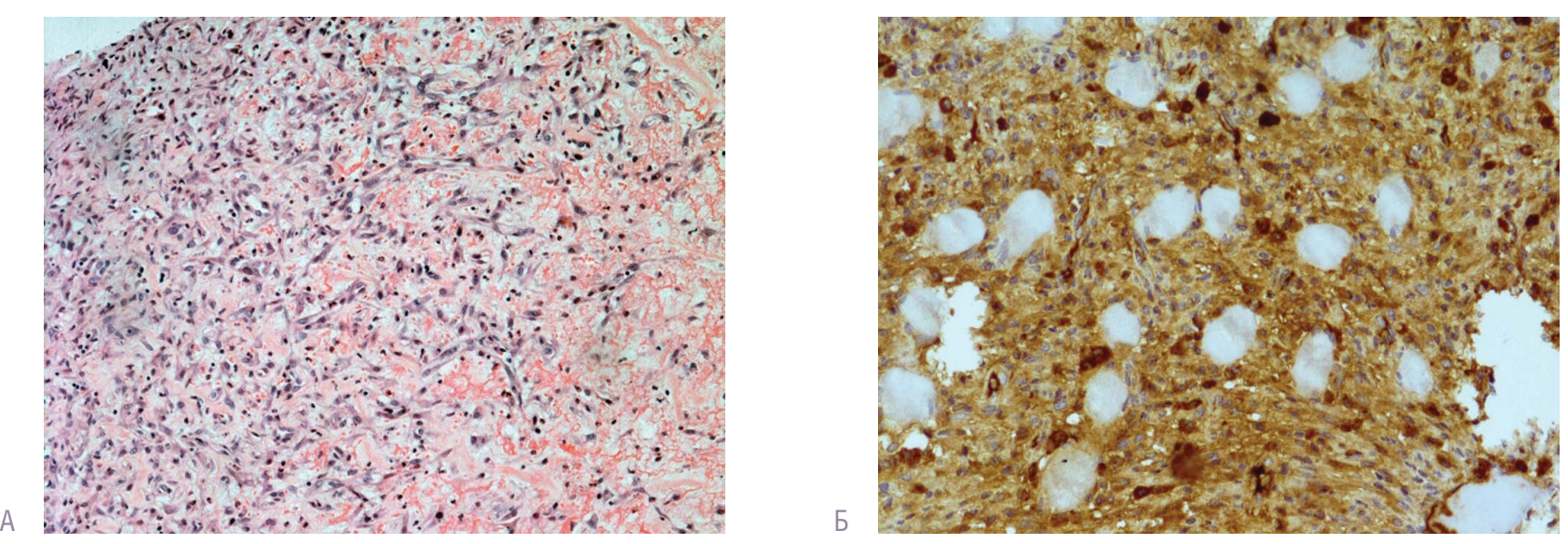

Рис. 11. Микроскопия мышечной ткани бедра экспериментальных животных 4-й группы (хроническая ишемия и введение тимолола) на 10-е сутки: А - Гематоксилин-
эозин, х200. Пролиферация фибробластов и эндотелиоцитов с тенденцией к образованию сети капилляров; Б- ИГХИ с антителами против СD34, х200. Полиморф--
ноклеточный инфильтрат. Слабовыраженные явления ангиогенеза
Fig. 11. Microscopy of the thigh muscle tissue in experimental group 4 (chronic ischemia and administration of timolol) on the 10 th day: A - Hematoxylin-eosin, $\times 200$. Prolifera-
tion of fibroblasts and endotheliocytes with a tendency to form a network of capillaries; Б — Immunohistochemistry with antibodies against CD34, ×200. Polymorphcellular
infiltrate. Mild angiogenesis phenomena
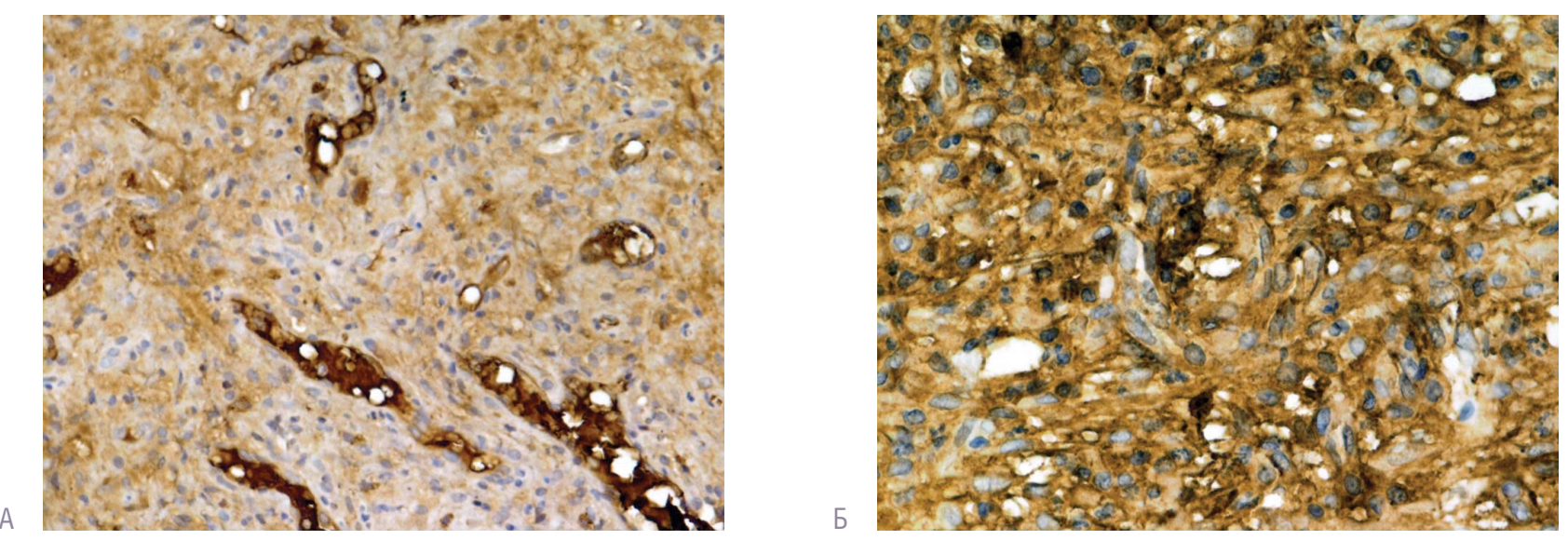

\begin{abstract}
Рис. 12. ИГХИ мышечной ткани бедра у экспериментальных животных 5-й и 6-й групп на 10-е сутки: А — ИГХИ с антителами против CD34, х200. Новообразованные сосуды с просветами. 5-я группа (хроническая ишемия и введение бетаксолола); Б - ИГХИ с антителами против CD34, ×400. Полиморфноклеточный инфильтрат. Начальные процессы ангиогенеза. 6-я группа (хроническая ишемия и введение интерферона альфа-2b)

Fig. 12. Immunohistochemistry of the thigh muscle tissue in experimental groups 5 and 6 on the 10th day: A - Immunohistochemistry with antibodies against CD34, $\times 200$. Newly-formed vessels with lumens. Group 5 (chronic ischemia and administration of betaxolol); 5 — Immunohistochemistry with antibodies against CD34, x400. Polymorphous cell infiltrate. Initial angiogenesis processes. Group 6 (chronic ischemia and administration of interferon alfa-2b)
\end{abstract}

Таблица 3. Результаты определения CD34+ $\left(p x^{2}, \%\right)$

Table 3. Determination of CD34+ $\left(p x^{2}, \%\right)$

\begin{tabular}{|c|c|c|c|c|c|c|c|c|c|c|c|c|}
\hline \multirow[b]{2}{*}{ Площадь } & \multicolumn{2}{|c|}{1 группа, n = 60} & \multicolumn{2}{|c|}{2 группа, $n=60$} & \multicolumn{2}{|c|}{3 группа, n = 60} & \multicolumn{2}{|c|}{4 группа, $n=60$} & \multicolumn{2}{|c|}{5 группа, $n=60$} & \multicolumn{2}{|c|}{6 группа, n = 60} \\
\hline & абс. & $\%$ & абс. & $\%$ & абс. & $\%$ & абс. & $\%$ & абс. & $\%$ & абс. & $\%$ \\
\hline Среднее & 10880,00 & 3,54 & 142102,02 & 46,26 & 40473,91 & 13,18 & 91555,33 & 29,80 & 127967,23 & 41,66 & 82838,02 & 26,97 \\
\hline Стандартное отклонение & 5222,58 & 1,70 & 32486,06 & 10,57 & 18034,30 & 5,87 & 13083,43 & 4,26 & 28878,79 & 9,40 & 19460,15 & 6,33 \\
\hline $\begin{array}{c}\text { Ошибка стандартного } \\
\text { отклонения }\end{array}$ & 674,23 & 0,22 & 4193,93 & 1,37 & 2328,22 & 0,76 & 1689,06 & 0,55 & 3728,24 & 1,21 & 2512,30 & 0,82 \\
\hline
\end{tabular}

группах (127 967,23 \pm 28 878,79 рх²), но превышала таковые в 3-й группе (положительный контроль, 40 473,91 \pm 18 034,30 рх²) (рис. 13).

Результаты микроскопии и ИГХИ свидетельствуют об отсутствии активации процессов неоангиогенеза в первой (контрольной) группе животных. У животных в условиях экспериментальной хронической ишемии (2-я группа) и в группе оперированных крыс, которым вводился селективный бета-адреноблокатор (бетаксолол, 5-я группа) наряду с выраженными воспалительными процессами (массивный полиморфноклеточный инфильтрат) установлены явления неоангиогенеза. 


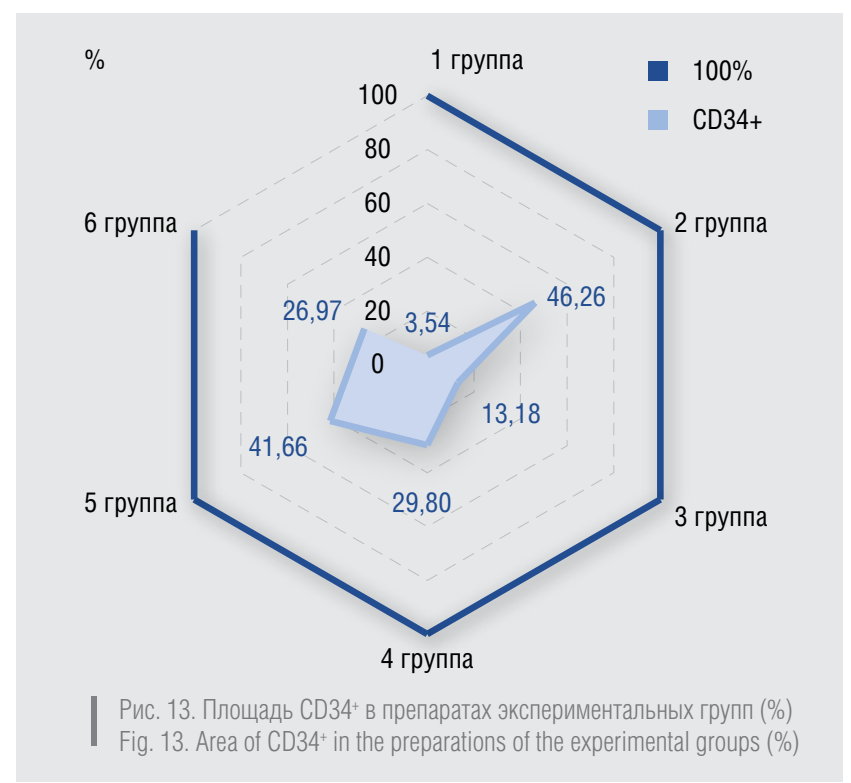

Характер неоангиогенеза в биоптатах животных 4-й и 6-й групп рассматривается как умеренно-выраженный. Практически полное отсутствие эндотелиоцитов установлено у крыс 3-й группы (животные в условиях хронической ишемии, которым вводился бевацизумаб).

Изучение клинической эффективности и безопасности тимолола, установило высокий профиль безопасности, в том числе при наружном применении и лечении детей с поверхностными очаговыми ювенильными гемангиомами [17], экспериментальные исследования in vitro указывают на полное отсутствие негативного влияния тимолола на жизнеспособность (LDH-тест и WST-1, модифицированный МTT-тест) эндотелиальных клеток, фрибробластов и кератиноцитов, миграцию и подвижность эндотелиальных клеток in vitro [18].
В совокупности с результатами настоящего исследования позволяют рассматривать тимолол как препарат выбора первой линии для консервативной патогенетически обоснованной терапии ювенильных гемангиом.

\section{Выводы}

Полученные результаты гистологических и ИГХ-исследований коррелируют с показателями ИФА VEGF в группах экспериментальных животных и состоянием ран - высокое угнетение VEGF при введении бевацизумаба (3-я группа), сходном антиангиогенном потенциале тимолола и интерферона $(7,22 \pm 1,24$ и 6,17 \pm 1,34 пг/мл соответственно, $\mathrm{p}=0,05)$ и меньшей активности селективного бета-адреноблокатора - бетаксолола (9,44 \pm 2,67 пг/мл, $p=0,05)$.

Индекс подавления VEGF указывает на высокую активность угнетения бевацизумабом VEGF (I VEGFSUP $=$ 28,28), умеренную при введении интерферона альфа-2b и раствора тимолола (8,33 и 5,14 соответственно), селективный бета-адреноблокатор бетаксолол оказывает наименьший эффрект в отношении VEGF $\left(I_{\text {VEGFSUP }}=1,26\right)$.

Таким образом, результаты проведенного исследования указывают на антиангиогенный потенциал бета-адреноблокаторов, которые проявляют прямое или опосредованное негативное влияние на синтез VEGF и угнетение неоангиогенеза. При этом активность селективного бета-адреноблокатора (бетаксолола) в отношении подавления неоангиогенеза была достоверно ниже по сравнению активностью неселективного (тимолола). Антиангиогенный эффрект тимолола в эксперименте практически сопоставим с активностью интерферона и достоверно отличается от показателей негативного контроля, что позволяет рассматривать данное средство как эфффективное и безопасное для профилактики и терапии ангиопролиферативных состояний, в том числе для местного лечения ювенильных гемангиом.

\section{Литература/References}

1. Frieden I. J. et al. Infantile hemangiomas: current knowledge, future directions, Proceedings of a research workshop on infantile hemangiomas. Pediatr Dermatol. 2005;22:383-406.

2. Дубенский Вл. В. Этиопатогенез и морфология ювенильных гемангиом. Российский журнал кожных и венерических болезней. 2014;(4):8-12. [Dubensky V. V. Etiopathogenesis and morphology of juvenile hemangiomas. Russian Journal of Skin and Venereal diseases. 2014;(4):8-12. (In Russ.)]

3. Дубенский Вл. В. Клинико-функциональные особенности ювенильных гемангиом. Современные проблемы дерматовенерологии, иммунологии, косметологии. 2013;(8):15-24. [Dubensky V. V. Clinical and functional features of juvenile hemangiomas. Modern Problems of Dermatovenerology, Immunology, Cosmetology. 2013;(8):15-24. (In Russ.)]

4. Drolet B., Frieden I. J. Characteristics of infantile hemangiomas as clues to pathogenesis. Does hypoxia connect the dots? Arch Dermatol. 2010;146:1295-1299.

5. Frieden I. J., Haggstrom A., Drolet B. A. et al. Infantile hemangiomas: current knowledge, future directions. Proceedings of a research workshop on infantile hemangiomas. Pediatr Dermatol Venereol. 2008;135:860-862.
6. North P. E., Waner M., Mizeracki A. et al. A unique microvascular phenotype shared by juvenile heamangiomas and human placenta. Arch Dermatol. 2001;137:559-570.

7. Barnes C. M., Christison-Lagay E. A., Folkman J. The placenta theory and the origin of infantile hemangioma. Lymphat Res Biol. 2007;5(4):245-255.

8. Hoeger P. H. Infantile Hemangioma: new aspects on the pathogenesis of the most common skin tumour in children. Br J Dermatol. 2011 Feb;164(2):234-235.

9. Razon M. J., Kraling B. M., Mulliken J. B., Bischoff J. Increase apoptosis coincides with onset of involution in infantile hemangioma. Microcirculation. 1998:5:189-195.

10. Léauté-Labrèze C., Dumas de la Roque E., Hubiche T., Boralevi F., Thambo J. B., Taïeb A. Propranolol for severe hemangiomas of infancy. N Engl J Med. 2008;358:2649-2651 [PubMed].

11. Drolet B. A., Frommelt P. C., Chamlin S. L., Haggstrom A., Bauman N. M., Chiu Y. E. et al. Initiation and use of propranolol for infantile hemangioma: report of a consensus conference. Pediatrics. 2013;131:128-140. 
12. D'Angelo $G$. et al. CAMP-dependant protein kinase inhibits the mitogenic action of vascular endothelial growth factor and fibroblast growth factor in capillary endothelial cells by blocking Raf activation. J. Cell Biochem. 1997;67:353-366.

13. Laccarino G. et al. Ischemic neoangiogenesis enhanced by beta2-adrenergic receptors overexpression: a novel role for the endothelial adrenergic system. Circ Res. 2005;97:1182-1189.

14. Тырсина Е. Г., Никулицкий С. И. Роль регуляторной VEGF/ VEGF-R1-системы в опухолевом ангиогенезе (обзор литературы). Онкогинекология. 2015. [Tyrsina E. G., Nikulitsky S. I. The role of the regulatory VEGF/NEGF-R1 system in tumour angiogenesis (literature review). Oncogynecology. 2015. (In Russ.)]

15. Кукес В. Г., Сычев Д. А., Андреев Д. А. Клиническая фармакология $\beta$-адреноблокаторов. РМЖ. 2005;14:932. [Kukes V. G., Sychev D. A., Andreev D. A. Clinical pharmacology of b-adrenoblockers. Breast cancer. Russian Medical Journal. 2005;14:932. (In Russ.)]
16. Миронов А. Н., Бунатян Н. Д. Руководство по проведению доклинических исследований лекарственных средств. М.: Гриф и К, 2012. 944 c. [Mironov A. N., Bunatyan N. D. Guidelines for conducting preclinical studies of drugs. Moscow: Grif i K, 2012. 944 p. (In Russ.)]

17. Дубенский В. В., Аун Р. Ю. Эффрективность и безопасность применения топического $\beta$-адреноблокатора для лечения ювенильных гемангиом. Фарматека. 2018;s1:32-39. [Dubensky V. V., Aun R. Yu. Efficacy and safety of topical $\beta$-blocker for the treatment of juvenile hemangiomas. Farmateka. 2018;s1:32-39. (In Russ.)]

18. Дубенский В.В.Влияние неселективного бета-адреноблокатора на хемотаксис и активную миграцию клеток in vitro в аспекте лечения ювенильных гемангиом. Иммунопатология, аллергология, инфектология. 2016;4:50-59. [Dubensky V. V. Effect of non-selective beta-adrenergic blocker on chemotaxis and in vitro active cell migration in the context of treating juvenile hemangiomas. Immunopathology, Allergology, Infectology. 2016;4:50-59. (In Russ.)]

\section{Информация об авторах}

Владислав Валерьевич Дубенский ${ }^{*}$ - к.м.Н., доцент, профессор кафедры дерматовенерологии с курсом косметологии Тверского государственного медицинского университета Министерства здравоохранения Российской Федерации; тел.: +7 (961) 016-00-00; e-mail: tgma.estet@yandex.ru

Валерий Викторович Дубенский - д.м.н., профессор, заведующий кафедрой дерматовенерологии с курсом косметологии Тверского государственного медицинского университета Министерства здравоохранения Российской Федерации

\section{Information about the authors}

Vladislav V. Dubensky* - Cand. Sci. (Med.), Assoc. Prof., Prof. of the Department of Dermatovenereology with a Course of Cosmetology, Tver State Medical University, Ministry of Health of the Russian Federation; tel.: +7 (961) 016-00-00; e-mail: tgma.estet@yandex.ru

Valery V. Dubensky - Dr. Sci. (Med.), Prof., Head of the Department of Dermatovenereology with a Course of Cosmetology, Tver State Medical University, Ministry of Health of the Russian Federation 